\title{
GAS EXCHANGE PARAMETERS IN RED COVER (TRIFOLIUM PRATENSE L.) AND FESTULOLIUM (FESTULOLIUM BRAUNII (K. RICHT) A. CAMUS) UNDER DROUGHT STRESS
}

\author{
STANIAK, M. ${ }^{1 *}-$ KSIĘŻAK, J. $^{1}-$ BOJARSZCZUK, J. ${ }^{1}-$ FELEDYN-SZEWCZYK, B. ${ }^{2}$ \\ ${ }^{I}$ Institute of Soil Science and Plant Cultivation - State Research Institute, Department of Forage \\ Crop Production, Czartoryskich 8, 24-100 Puławy, Poland \\ ${ }^{2}$ Institute of Soil Science and Plant Cultivation - State Research Institute, Department of \\ Systems and Economics of Crop Production, Czartoryskich 8, 24-100 Puławy, Poland \\ (phone: +48-81-478-6790; fax: +48-81-478-6900) \\ *Corresponding author \\ e-mail: staniakm@iung.pulawy.pl \\ (Received $5^{\text {th }}$ Sep 2018; accepted 26 $6^{\text {th }}$ Nov 2018)
}

\begin{abstract}
Water deficit in the soil is one of the factors that limit the yield of crops, causing great damage to agricultural production. This is the result of genotypic expression as modulated by interaction with the environment. The effect of water deficit on gas exchange parameters of Festulolium hybrid and red clover grown in pure stand and in mixture were studied. Two-factor pot experiment was performed in the completely randomized block method, with four replications. Objects were evaluated at two soil moisture levels: well-watered conditions and drought stress. The studies have shown that all the measured parameters were affected by drought stress. Net photosynthetic rate, transpiration rate and stomatal conductance were significantly lower under drought stress than under well-watered conditions in all treatments. Red clover grown in a pure stand responded to stress the most, while Festulolium hybrid - the least. It was also found that the highest water use efficiency index (WUE) was observed in Festulolium which proves a more economical water management compared to red clover. The mixtures showed smaller yield losses under drought stress compared to red clover grown in pure stand, which indicates their higher suitability to be grown in areas with less rainfall.
\end{abstract}

Keywords: photosynthesis, transpiration, stomatal conductance, water-use efficiency

\section{Introduction}

The frequency of extreme climatic events has increased due to global climate change. Environmental stresses are limiting factors for production of important agricultural crops worldwide. According to $\mathrm{Li}$ et al. (2011), $25 \%$ of the world's agricultural land is under the influence of drought stress, limiting growth, development and productivity of many forage crops. It is argued that breeding of forage species should aim to improve plant strategies to cope with relevant abiotic stresses and optimize growth and phenology to new seasonal variation, and that plant diversity at all levels is a good adaptation strategy (Ergon et al., 2018).

Agriculture is based mainly on rainwater, which is why frequent rainfall is a real threat to agricultural production. Water shortage causes the inhibition of plant growth and development processes as well as disrupts physiological processes, including photosynthesis. It also disrupts the transport and distribution of assimilates (Starck, 2010). Stress leads to disturbance of water balance of the plant, through the decrease of water potential in cells and accumulation of secondary metabolites, which on the one hand, reduce the osmotic potential, but on the other hand, protect the cellular structures. The prolonged stress damages the thylakoid membranes and degradation of lipids 
stabilizing protein complexes, which consequently leads to damage to photosystems, mainly PSII. The photosynthetic apparatus exhibits a particular sensitivity to stress factors, which is why it is the first to react to any changes in the environment. Drought inhibits the intensity of photosynthesis, which is probably caused by a decrease in RuBisCo activity and a decrease in diffusion conductivity, which in turn, limits the availability of $\mathrm{CO}_{2}$ in intercellular spaces (Hura et al., 2007). Under optimal cultivation conditions, the yield of plants depends on the intensity of the photosynthesis and is reduced by the loss of biomass due to respiration process. According to Lawlor (1995), nearly $90 \%$ of the accumulated biomass depends on the intensity of the photosynthesis.

The response of individual species to abiotic stresses may vary considerably. First and foremost, this is determined by genetic determinants, but also by a number of external factors, such as: light intensity, temperature, water availability, oxygen and carbon dioxide concentration in the air; and internal factors, such as: leaf structure, chlorophyll content, enzyme activity, or mineral supply (Starck, 2010). From the point of view of yield biology, the plant is resistant to stress, when under unfavourable environmental conditions, it can yield a little less than under optimal conditions (Dziadczyk, 2002). According to Blum (2009), this may be associated with the formation of a larger mass of roots, longer roots, or with the increased root permeability. Olszewska (2008) reported that, the intensity of gas exchange processes also depends on the type of plant cultivation. Compared to monotypic sowing, mixtures are generally less susceptible to adverse environmental conditions due to varied environmental requirements of individual components, different development rhythm, and differences in root system morphology. This makes mixtures yield better and be more reliable in cultivation (Lucero et al., 1999; Hakala and Jauhiainen, 2007).

Red clover (Trifolium pratense L.) is an important forage legume to world agriculture because of their environmental and agricultural benefits. It is an assort-lived perennial legume, meaning that it is only productive for two to three years and harvested three to five times a year (OMAFRA, 2011; Tucak et al., 2016). The short persistence of red clover grown in pure stand is mainly due to poor overwintering which can be caused by physical damage, e.g. low temperature and ice cover and pathogens, especially root rot and clover root for which deep snow cover provides ideal conditions (Hakala and Jauhiainen, 2007). Red clover needs at least 500-600 mm of annual precipitation to properly develop, including 300-400 $\mathrm{mm}$ during vegetation period (Rojek, 1986). The greatest demand for water is in the period of intensive growth, that is, in the phase of forming main shoots and branches and developing inflorescences. Red clover grows best in a humid, moderately cold climate, under frequent and evenly distributed rainfall during the growing season (OMAFRA, 2011). Several multi-year studies showed that red clover biomass weight was lower in years with less than average precipitation, suggesting that red clover may be susceptible to drought stress. Grasses have high water requirements as well. Their daily demand varies from 0.5 to $3.0 \mathrm{dm}^{3} \cdot \mathrm{m}^{-2}$, and the amount of water transpired from $1 \mathrm{~m}^{2}$ of grass sward per year can amount up to $1000 \mathrm{dm}^{3}$ (Thomas, 1994). According to Labędzki (2006), drought during the summer, accompanied by high temperature, can cause a decrease in grass yield by about $30 \%$.

Growing perennial legume-grass mixtures has many benefits. In addition to being valuable, balanced feed for ruminants, mixtures reduce weeds, protect the soil from erosion by rain and wind, increase soil organic matter and soil fertility, improve soil water-holding capacity, and improve to soil structure and yield stability (Gaudin et al., 
2013). Mixtures allow improved resource utilisation and beneficial biological interactions between the crops. Successful mixtures relies on the component crops having complementary rather than competing traits and thus using resources more efficiently than pure crops. They also require smaller doses of mineral nitrogen than grasses grown in pure sowing, due to ability of legumes to fix atmospheric $\mathrm{N}$, utilizing a symbiotic relationship with Rhizobium trifolii. Red clover contributes a large amount of naturally produced nitrogen to the soil for use by companion grasses (Queen et al., 2009). It provides them with a unique advantage compared to other plant species. With the increase of energy cost, $\mathrm{N}$-fertiliser has become more expensive, a trend that is expected to continue in the future, which will likely further increase the need of legume production, including red clover (Jensen and Hauggaard-Nielsen, 2003).

Knowledge about the physiological and genetic responses of grasses and legumes to drought stress is insufficient. It is predicted that climate change may increase the risk of local droughts, with severe consequences for agricultural practises (Lipiec et al., 2013). This indicates a need to conduct research aimed at recognizing and understanding the responses of various crop species to adverse environmental factors and their possibilities of adapting and acclimatizing to changing conditions. This will allow a bigger use of drought-resistant species resistant, which can effectively use habitat resources and exhibit good water management. High hopes are placed on interspecific and intergeneric hybrids, which combine beneficial traits of parental species in their genomes. They constitute a valuable source of variability for increasing resistance to abiotic and biotic stresses. One of such hybrids is Festulolium (Festulolium braunii (K. Richt) A. Camus), the effect of the crossing of italian ryegrass (Lolium multiflorum Lam.) and meadow fescue (Festuca pratensis Huds.) (Østrem et al., 2013). According to Kryszak et al. (2002) Festulolium give higher yields by about $20 \%$ in comparison to red clover. For this reason, it is used in intensive feed production and sown on arable land and temporary grasslands, both in pure sowing and in mixtures with legumes (Olszewska, 2008). Festulolium is one of the most used species in Denmark (Elgersma and Søegaard, 2018).

The aim of the study was to compare gas exchange parameters of Festulolium and red clover grown both in pure stands and in mixture under conditions of optimal soil moisture and long-term drought stress.

\section{Materials and methods}

\section{Plant material and growth conditions}

The research was based on a two-factors pot experiment carried out in 2012-2014, in a greenhouse of the Institute of Soil Science and Plant Cultivation - State Research Institute in Puławy, in Poland [51 $\left.{ }^{\circ} 24^{\prime} 59^{\prime \prime} \mathrm{N}, 21^{\circ} 58^{\prime} 9^{\prime \prime} \mathrm{E}\right]$ in the completely randomized block method, with four replications. Festulolium hybrid cultivar Agula and red clover tetraploid cultivar Bona were grown in pure stands and in mixture (50\% grass $+50 \%$ legume). Objects were assessed at two soil moisture levels: $70 \%$ field water capacity (FWC) as optimum moisture content and 40\% FWC as drought stress. Soil moisture content was differentiated 8 weeks after sowing, in the second and third year of growing -2 weeks after starting of vegetation. In order to maintain the appropriate soil moisture, water losses were made up on a daily basis, to achieve a specified weight of the pot with soil. The treatments were stop after last cut and plants were watered as needed. During the day pots where standing outside and during the night inside the 
greenhouse. Temperature of the air in greenhouse was similar to the temperature outside. Average temperature in Puławy, for the years 2012-2014 during vegetation months (IV-X) was respectively: 9.7, 15.2, 17.8, 20.8, 19.0, 13.7, $9.1{ }^{\circ} \mathrm{C}$. In winters pots were in greenhouse, where the lowest temperature did not fall under $0{ }^{\circ} \mathrm{C}$. The pots were cuts every 4-5 weeks in the flowering stage of red clover, on the height of $4-5 \mathrm{~cm}$.

The Mitcherlich pots were filled with $7 \mathrm{~kg}$ of lessive soil from arable layer (0$30 \mathrm{~cm}$ ). It was characterized by a neutral reaction ( $\mathrm{pH}$ in $1 \mathrm{M} \mathrm{KCl} \mathrm{7.4),} \mathrm{the} \mathrm{available}$ nutrient content of the soil was as follows ( $\mathrm{mg} \cdot 100 \mathrm{~g}^{-1}$ soil): phosphorus 24.8 , potassium 14.2 and magnesium 2.2.

The seeds were sown in 11 of April 2012, three seeds at 15 points in each pot. After emergence poorly developed seedlings were removed, leaving 8 plants per pot (in mixture -4 units of Festulolium and 4 units of red clover). This proportion lasted over three years. The soil material was fortified with mineral fertilizers at doses $\left(\mathrm{g}^{\mathrm{p}} \mathrm{pot}^{-1}\right)$ : $0.5 \mathrm{~N}, 1.0 \mathrm{P}, 1.5 \mathrm{~K}, 0.5 \mathrm{Mg}$ in the form of solutions: $\mathrm{NH}_{4} \mathrm{NO}_{3}, \mathrm{KH}_{2} \mathrm{PO}_{4}, \mathrm{~K}_{2} \mathrm{SO}_{4}$ and $\mathrm{MgSO}_{4} \times 7 \mathrm{H}_{2} \mathrm{O}$ before sowing and $0.5 \mathrm{~N}$ after each cut of Festulolium in pure stand and half of this dose after each cut of mixture. Red clover in pure stand was not fertilized by nitrogen (except of start dose).

\section{Methods and measurements}

Gas exchange parameters and dry mass yield (DMY) were evaluated. Physiological plants parameters: net photosynthetic rate $\left(\mathrm{P}_{\mathrm{N}}\right)$, transpiration rate $(\mathrm{E})$ and stomatal conductance $\left(\mathrm{g}_{\mathrm{s}}\right)$, were measured with an apparatus CIRAS-2 Portable Photosynthesis System (USA), a 1-2 days before each cut. Leaf gas exchange parameters were measured between 7.00-11.00 am, on the second fully exposed leaf in six replications, at a concentration of $390 \mathrm{ppm} \mathrm{CO}, 1000-1200 \mathrm{PAR}\left[\mu \mathrm{mol} \cdot \mathrm{m}^{-2} \cdot \mathrm{s}^{-1}\right]$ and $17-25^{\circ} \mathrm{C}$. Water use efficiency (WUE) was calculated based on the quotient of instantaneous values of photosynthesis and transpiration $\left(\mathrm{P}_{\mathrm{N}} / \mathrm{E}\right)$. Plant material for the research was collected three times during the first growing season, and four times during second and third vegetation year.

The agricultural drought index, determining crop reductions due to water shortage in the soil, was calculated according to the formula (Labędzki, 2006):

$$
\mathrm{YR}=1-\left(\mathrm{Y}_{\mathrm{re}} \cdot \mathrm{Y}_{\mathrm{p}}^{-1}\right)
$$

where:

YR - agricultural drought index, quantizing the yield reduction,

$\mathrm{Y}_{\mathrm{re}}-$ yield reduced due soil water deficit,

$\mathrm{Y}_{\mathrm{p}}$ - potential yield under optimal soil moisture.

\section{Statistical analysis}

The date presented are the mean values from the years 2012-2014, as a result of a similar reaction of the plant examined to different soil moisture uncovered during three study years. The results were statistically analysed with the use of the analysis of variance for the completely randomized design, using Statistica v.10.0 program. Tukey's multiple comparison test was used to compare differences between the means for main effects (factors), while confidence intervals for the means of $\operatorname{LSD}(\alpha=0.05)$ were used to compare the means from the subclasses (interactions). 


\section{Results}

The effect of the main factors soil moisture (SM) and treatment $(\mathrm{T})$ as well as that of the interactions $\mathrm{SM} \times \mathrm{T}$ on $\mathrm{P}_{\mathrm{N}}, \mathrm{E}, \mathrm{g}_{\mathrm{s}}$, WUE were in most cases significant $(\mathrm{p}<0.05)$ in all regrowth and average value. Drought stress led to significant decrease in photosynthesis and transpiration rate, stomatal conductance and increased in water use efficiency of red clover and Festulolium grown in pure stand and in mixture.

An important factor shaping the level of plant yield is the intensity of leaf gas exchange processes. An analysis of research results showed that red clover and Festulolium grown in pure and mixed stand reacted differently to stress. In all the years of research, in the optimal moisture conditions, the red clover cultivated in pure stand assimilated carbon dioxide the most effectively (Table 1). Under stress caused by the limit of moisture in the soil, the tested species responded with a significant reduction in the rate of photosynthesis (on average by $12.6 \%$ in the first, by $20.1 \%$ in the second, and $22.7 \%$ in the third year of vegetation). The strongest response to the water deficit in the first and third year of vegetation was noted for red clover cultivated in pure stand, where the average photosynthesis rate decreased by 16.8 and $34.6 \%$ respectively, while the red clover cultivated in the mixture demonstrated the highest rate of this process (9.48 and $16.15 \mu \mathrm{mol} \mathrm{CO} \mathrm{CO}_{2} \cdot \mathrm{m}^{-2} \cdot \mathrm{s}^{-1}$ ), compared to the optimally moistened treatments. In the second year of vegetation, the decrease in the rate of photosynthesis under drought stress was the biggest in Festulolium. Moreover, this hybrid cultivated in mixture showed significantly higher rate of photosynthesis under drought stress in relations to its cultivation in pure stand. Analysing individual regrowths, it was found that the largest assimilation of carbon dioxide by plants in the first year of vegetation occurred in the third regrowth, while in the second and third year - in the first, second and third regrowth. The calculated values of determination coefficients $\left(\mathrm{R}^{2}=58 \%\right.$ in the first, $\mathrm{R}^{2}=49 \%$ in the second, and $\mathrm{R}^{2}=69 \%$ in the third year of vegetation) and regression equations showed a significant, positive relationship between the photosynthetic rate and dry mass of the species tested in all years of research (Fig. 1). This dependency was directly proportional, which indicates a highly significant influence of the intensity of this process on the yield of the tested species.

A significant variability was recorded in the intensity of water transpiration from the leaf surface in red clover and Festulolium grown under limited and optimal soil moisture. In all vegetation years, the highest rate of transpiration was noted for red clover cultivated in pure stand (Table 2). Both species responded to water deficiency in soil with a significant reduction in the rate of this process (averagely by $29.5 \%$ in the first, $21.2 \%$ in the second and $31.5 \%$ in the third year of vegetation), compared to the optimally moistened treatments. Species cultivated in pure stand limited the evaporation of water from their leaf surface under stress conditions more than under mixed stand, whereas the smallest difference was found in the Festulolium hybrid grown in mixture. A statistical analysis of the results showed a highly significant, positive relationship between the rate of transpiration and the dry mass yield of red clover and Festulolium in all the years of the research, as evidenced by high values of determination coefficients $\left(\mathrm{R}^{2}=74 \%, \mathrm{R}^{2}=65 \%\right.$ and $\mathrm{R}^{2}=87 \%$, respectively) (Fig. 2).

Under stress conditions, the studied species had significantly lower values of stomatal conductance (on average by $27.8 \%$ in the first, by $43.8 \%$ in the second, and by $51.6 \%$ in the third year of vegetation) compared to optimal conditions (Table 3). Irrespective of the method of cultivation and the level of soil moisture, red clover showed higher values of this parameter in the first and third year of vegetation, while 


$$
-218 \text { - }
$$

the Festulolium hybrid - in the second year of vegetation. Significantly higher values of stomatal conductance, regardless of the level of soil moisture, were recorded in the second and third year of vegetation than in the first. The calculated values of determination coefficients and regression equations showed a significant, positive relationship between stomatal conductance and dry mass yield of red clover and Festulolium in all the years of the study $\left(\mathrm{R}^{2}=63 \%, \mathrm{R}^{2}=68 \%\right.$ and $\mathrm{R}^{2}=87 \%$, respectively) (Fig. 3). This dependency was directly proportional, which shows a highly significant effect of this process on the yields of the tested species.
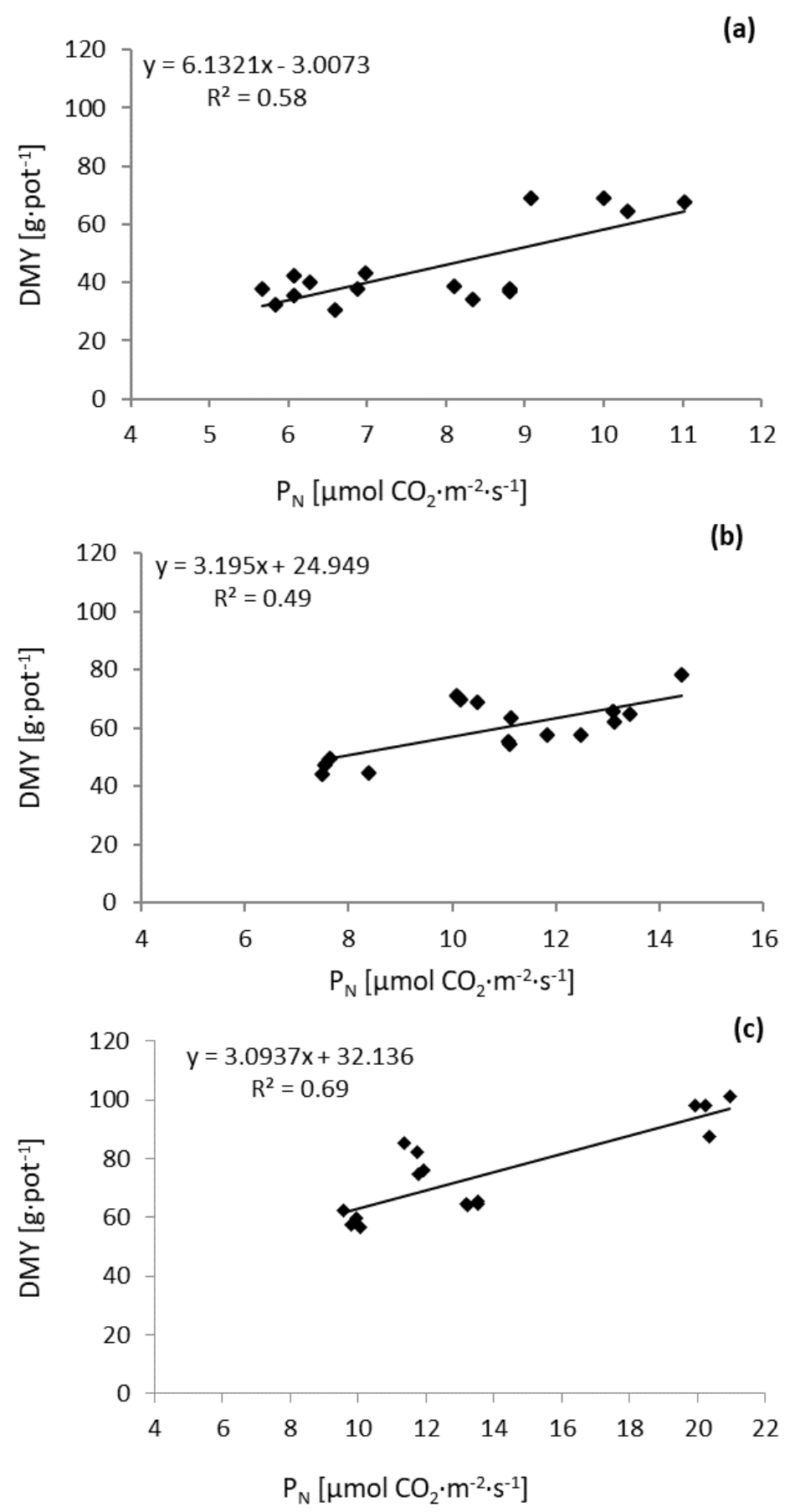

Figure 1. Relationship between net photosynthetic rate $\left(P_{N}\right)$ and dry mass yield $(D M Y)$ in the years: 2012 (a), $2013(b), 2014(c)$ 


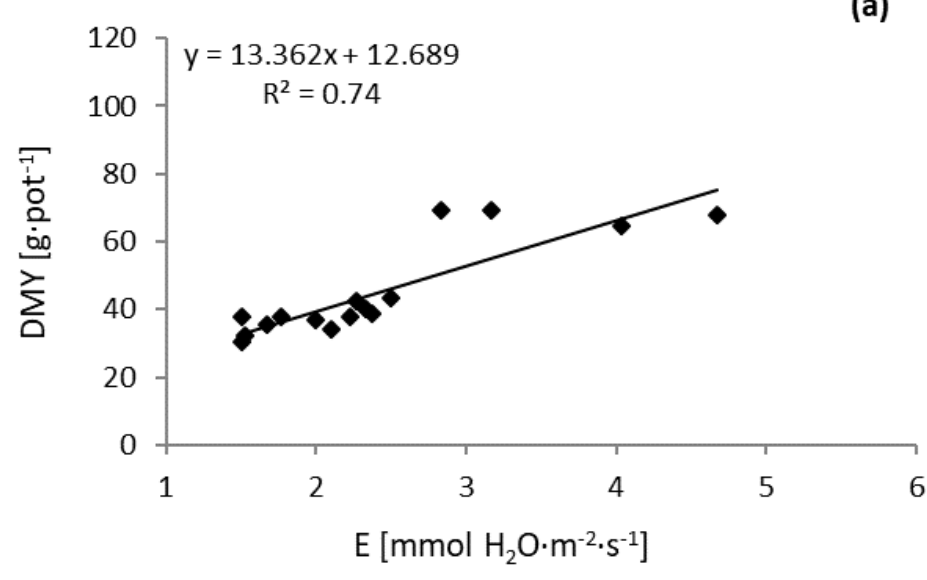

(b)

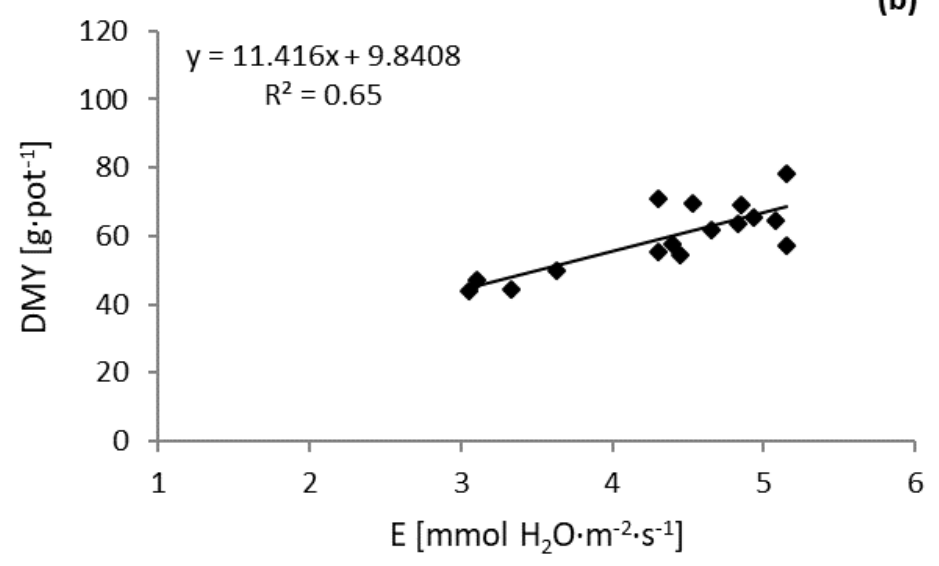

(c)

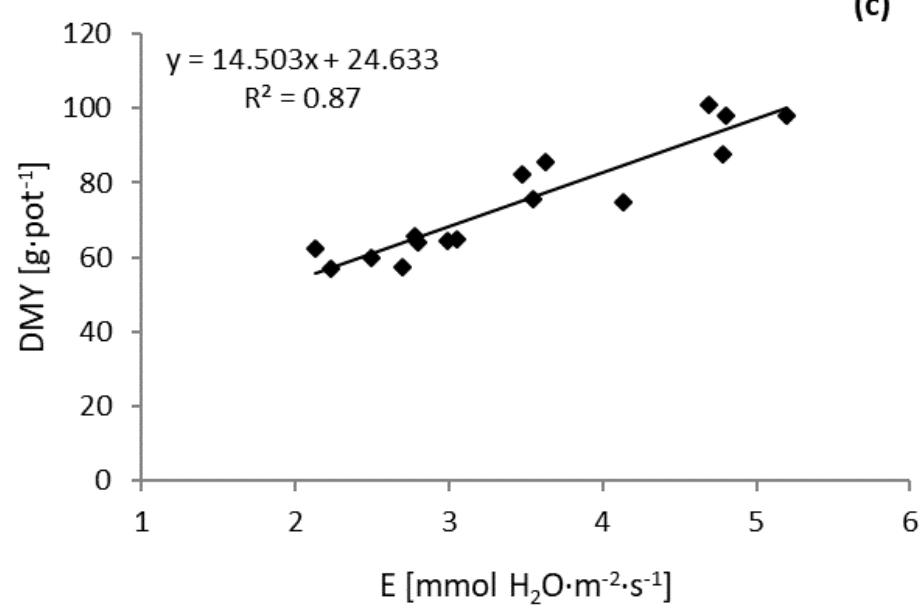

Figure 2. Relationship between transpiration rate $(E)$ and dry mass yield (DMY) in the years: $2012(a), 2013(b), 2014(c)$

Water use efficiency (WUE index) in red clover and Festulolium was generally higher under stress conditions caused by water deficit in the soil than under optimal moisture conditions (averagely for treatments by $22.1 \%$ in the first, by $5.2 \%$ in the second, and by $13.0 \%$ in the third year of vegetation) (Table 4). In the first year of vegetation significant differences were found in those species, which were grown in 


$$
-220 \text { - }
$$

pure stand, in the third year - in red clover cultivated in a mixture and Festulolium in pure stand. In the second year of vegetation, there was no significant difference in the water use efficiency among particular species, the way in their cultivation and the level of soil moisture, but only the tendency to more economical water management for crops grown in long-term drought conditions.
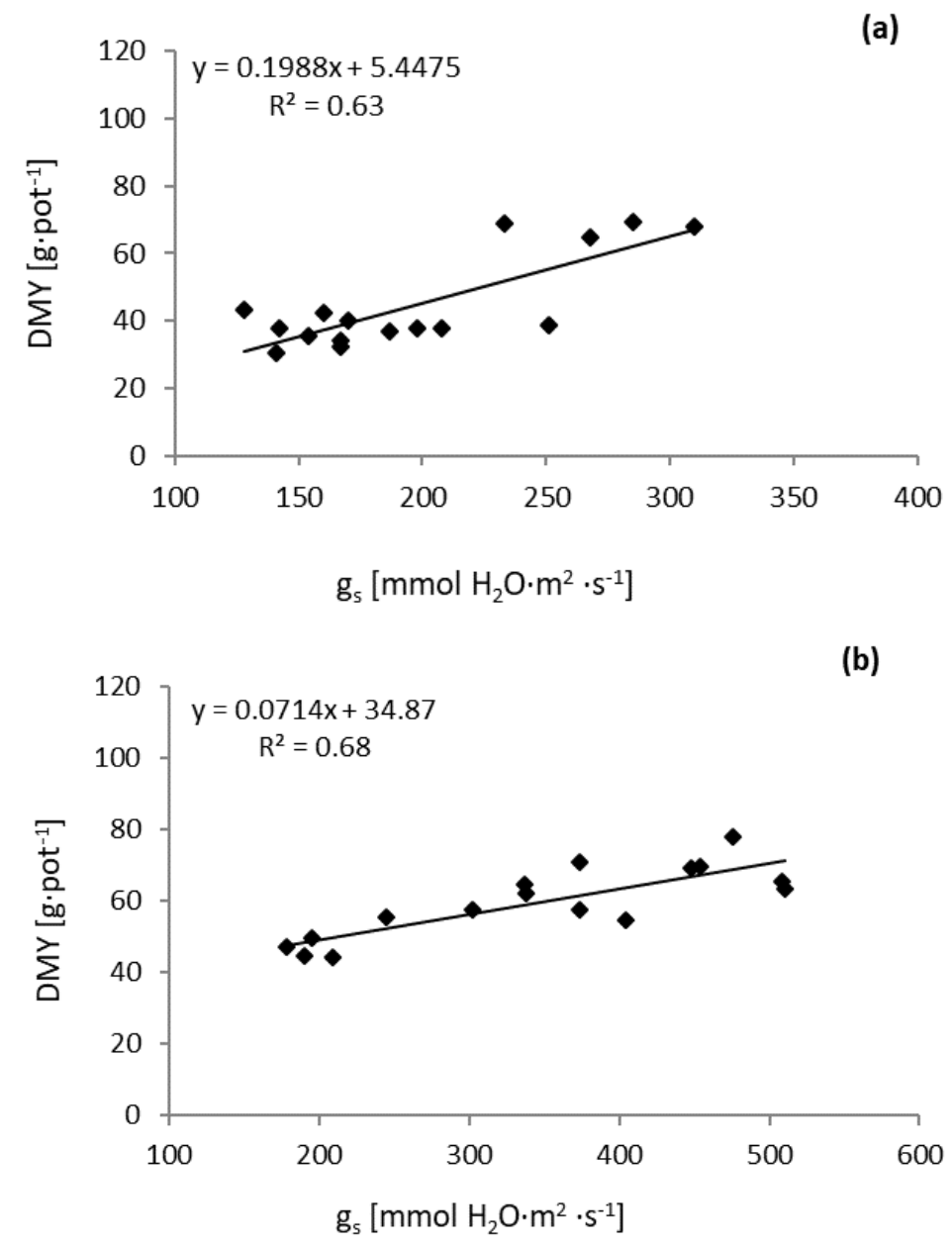

(c)

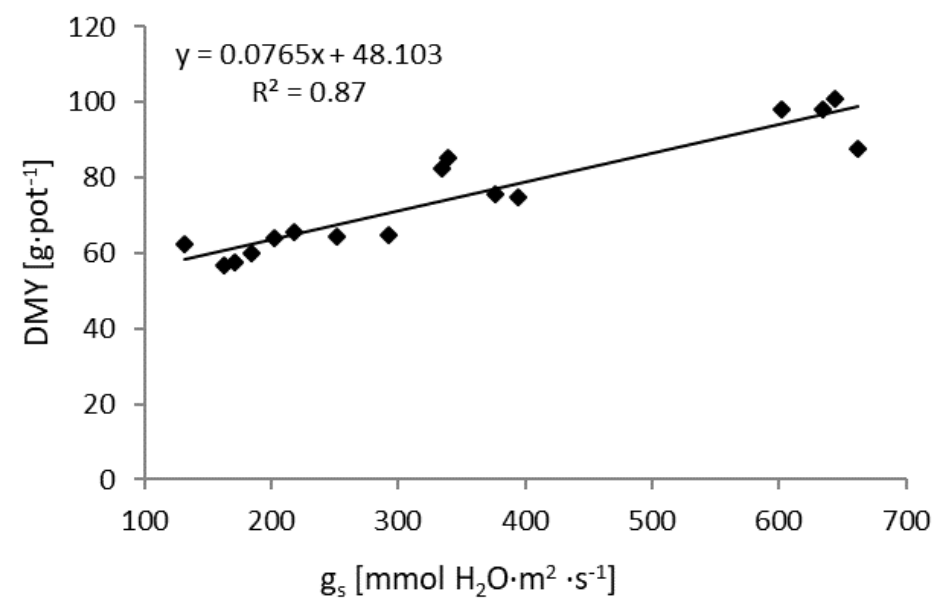

Figure 3. Relationship between stomatal conductance $\left(g_{s}\right)$ and dry mass yield (DMY) in the years: $2012(a), 2013(b), 2014(c)$ 
Table 1. Net photosynthetic rate $\left(P_{N}\right)$ of red clover and Festulolium grown in pure stand and in mixture under optimal and drought stress conditions $\left[\mu \mathrm{mol} \mathrm{CO}_{2} \mathrm{~m}^{-2} \mathrm{~s}^{-1}\right]$ (mean \pm standard deviation, $\left.n=6\right)$

\begin{tabular}{|c|c|c|c|c|c|c|c|c|c|c|}
\hline \multirow{3}{*}{ Treatment } & \multicolumn{2}{|c|}{ I regrowth } & \multicolumn{2}{|c|}{ II regrowth } & \multicolumn{2}{|c|}{ III regrowth } & \multicolumn{2}{|c|}{ IV regrowth } & \multicolumn{2}{|c|}{ Average $^{3}$} \\
\hline & \multicolumn{10}{|c|}{ Soil moisture conditions } \\
\hline & Optimum & Stress & Optimum & Stress & Optimum & Stress & Optimum & Stress & Optimum & Stress \\
\hline \multicolumn{11}{|c|}{2012} \\
\hline Red clover PS ${ }^{1}$ & $4.62 \pm 0.63$ & $3.30 \pm 1.11$ & $6.70 \pm 2.27$ & $4.33 \pm 0.73$ & $19.7 \pm 2.26$ & $18.2 \pm 1.40$ & - & - & $10.3 \pm 1.49$ & $8.60 \pm 0.59$ \\
\hline Red clover $\mathrm{MX}^{2}$ & $7.80 \pm 1.86$ & $4.58 \pm 1.27$ & $3.98 \pm 0.68$ & $3.83 \pm 0.76$ & $20.4 \pm 2.79$ & $20.0 \pm 1.47$ & - & - & $10.7 \pm 1.20$ & $9.48 \pm 0.99$ \\
\hline Festulolium PS & $6.83 \pm 1.04$ & $6.57 \pm 1.26$ & $3.47 \pm 0.52$ & $2.50 \pm 0.51$ & $9.63 \pm 1.92$ & $9.15 \pm 1.20$ & - & - & $6.65 \pm 0.72$ & $6.07 \pm 0.56$ \\
\hline Festulolium MX & $5.27 \pm 0.92$ & $4.98 \pm 1.19$ & $2.77 \pm 0.63$ & $2.53 \pm 0.48$ & $7.00 \pm 1.98$ & $5.78 \pm 1.12$ & - & - & $5.01 \pm 0.71$ & $4.43 \pm 0.53$ \\
\hline $\operatorname{LSD}(\alpha=0.05)$ & \multicolumn{2}{|c|}{1.88} & \multicolumn{2}{|c|}{1.54} & \multicolumn{2}{|c|}{ n.s. ${ }^{4}$} & & & \multicolumn{2}{|c|}{$\begin{array}{l}\text { n.s. } \\
\end{array}$} \\
\hline ANOVA summary & f-ratio & $\mathrm{p}$ & f-ratio & $\mathrm{p}$ & f-ratio & $\mathrm{p}$ & - & - & f-ratio & $\mathrm{p}$ \\
\hline Soil moisture SM & 13.19 & $<0.001$ & 10.47 & 0.002 & 2.89 & 0.097 & - & - & 15.39 & $<0.001$ \\
\hline Treatment $\mathrm{T}$ & 12.08 & $<0.001$ & 19.98 & $<0.001$ & 165.59 & $<0.001$ & - & - & 93.67 & $<0.001$ \\
\hline $\mathrm{SM} \times \mathrm{T}$ & 3.93 & 0.015 & 3.19 & 0.034 & 0.26 & 0.855 & - & - & 1.15 & 0.341 \\
\hline \multicolumn{11}{|c|}{2013} \\
\hline Red clover PS & $11.2 \pm 2.37$ & $8.92 \pm 1.55$ & $15.0 \pm 1.64$ & $14.8 \pm 0.67$ & $18.7 \pm 1.64$ & $13.6 \pm 1.12$ & $8.43 \pm 0.86$ & $7.05 \pm 1.76$ & $13.3 \pm 1.03$ & $11.1 \pm 1.03$ \\
\hline Red clover MX & $12.1 \pm 2.33$ & $8.70 \pm 2.46$ & $6.88 \pm 1.00$ & $6.00 \pm 0.95$ & $9.73 \pm 0.96$ & $9.07 \pm 1.37$ & $7.12 \pm 1.53$ & $6.00 \pm 2.31$ & $8.97 \pm 0.67$ & $7.44 \pm 0.57$ \\
\hline Festulolium PS & $9.22 \pm 1.69$ & $8.10 \pm 1.76$ & $9.27 \pm 1.18$ & $9.85 \pm 0.89$ & $14.7 \pm 1.78$ & $8.63 \pm 1.58$ & $7.88 \pm 1.09$ & $5.67 \pm 1.07$ & $10.3 \pm 0.59$ & $8.06 \pm 0.93$ \\
\hline Festulolium MX & $11.9 \pm 3.90$ & $10.2 \pm 3.78$ & $16.2 \pm 4.11$ & $11.4 \pm 1.94$ & $16.5 \pm 2.62$ & $11.8 \pm 2.15$ & $8.57 \pm 1.10$ & $6.87 \pm 1.62$ & $13.3 \pm 0.59$ & $10.1 \pm 1.73$ \\
\hline $\operatorname{LSD}(\alpha=0.05)$ & \multicolumn{2}{|c|}{ n.s. } & \multicolumn{2}{|c|}{2.93} & \multicolumn{2}{|c|}{2.68} & \multicolumn{2}{|c|}{ n.s. } & \multicolumn{2}{|c|}{1.49} \\
\hline ANOVA summary & f-ratio & $\mathrm{p}$ & f-ratio & $\mathrm{p}$ & f-ratio & $\mathrm{p}$ & f-ratio & $\mathrm{p}$ & f-ratio & $\mathrm{p}$ \\
\hline Soil moisture SM & 7.80 & 0.008 & 4.02 & 0.051 & 68.28 & $<0.001$ & 13.90 & $<0.001$ & 63.72 & $<0.001$ \\
\hline Treatment T & 1.78 & 0.166 & 72.70 & $<0.001$ & 34.93 & $<0.001$ & 2.08 & 0.118 & 57.29 & $<0.001$ \\
\hline $\mathrm{SM} \times \mathrm{T}$ & 0.43 & 0.733 & 14.28 & $<0.001$ & 5.65 & 0.002 & 0.30 & 0.823 & 3.47 & 0.024 \\
\hline \multicolumn{11}{|c|}{2014} \\
\hline Red clover PS & $22.7 \pm 1.22$ & $12.3 \pm 1.63$ & $23.2 \pm 1.59$ & $15.6 \pm 1.40$ & $22.8 \pm 0.70$ & $16.0 \pm 1.12$ & $12.9 \pm 0.97$ & $9.40 \pm 1.38$ & $20.4 \pm 0.54$ & $13.3 \pm 0.25$ \\
\hline Red clover MX & $20.2 \pm 3.44$ & $17.5 \pm 1.86$ & $22.7 \pm 2.85$ & $15.7 \pm 4.44$ & $21.4 \pm 1.27$ & $20.9 \pm 0.54$ & $11.1 \pm 0.96$ & $10.5 \pm 2.37$ & $18.8 \pm 1.14$ & $16.2 \pm 0.55$ \\
\hline Festulolium PS & $15.2 \pm 0.93$ & $12.4 \pm 1.08$ & $12.5 \pm 1.30$ & $10.8 \pm 0.58$ & $11.2 \pm 1.25$ & $10.6 \pm 0.63$ & $7.83 \pm 0.76$ & $5.80 \pm 1.44$ & $11.7 \pm 0.29$ & $9.91 \pm 0.52$ \\
\hline Festulolium MX & $12.8 \pm 1.86$ & $11.7 \pm 1.60$ & $11.7 \pm 0.72$ & $11.0 \pm 1.30$ & $13.7 \pm 1.10$ & $9.13 \pm 1.00$ & $9.47 \pm 0.79$ & $4.77 \pm 0.95$ & $11.9 \pm 0.61$ & $9.16 \pm 0.29$ \\
\hline $\operatorname{LSD}(\alpha=0.05)$ & \multicolumn{2}{|c|}{2.87} & \multicolumn{2}{|c|}{3.31} & \multicolumn{2}{|c|}{1.54} & \multicolumn{2}{|c|}{2.02} & \multicolumn{2}{|c|}{0.92} \\
\hline ANOVA summary & f-ratio & $\mathrm{p}$ & f-ratio & $\mathrm{p}$ & f-ratio & $\mathrm{p}$ & f-ratio & $\mathrm{p}$ & f-ratio & $\mathrm{p}$ \\
\hline Soil moisture SM & 61.90 & $<0.001$ & 47.09 & $<0.001$ & 117.5 & $<0.001$ & 51.54 & $<0.001$ & 432.0 & $<0.001$ \\
\hline Treatment $\mathrm{T}$ & 32.77 & $<0.001$ & 52.85 & $<0.001$ & 345.8 & $<0.001$ & 37.89 & $<0.001$ & 481.3 & $<0.001$ \\
\hline $\mathrm{SM} \times \mathrm{T}$ & 15.16 & $<0.001$ & 8.17 & $<0.001$ & 28.84 & $<0.001$ & 5.62 & 0.002 & 47.56 & $<0.001$ \\
\hline
\end{tabular}

${ }^{1} \mathrm{PS}$ - species grown in pure stand; ${ }^{2} \mathrm{MX}$ - species grown in mixture; ${ }^{3}$ average over the three (2012) or four regrowth (2013, 2014); ${ }^{4}$ n.s. - not significant 
Table 2. Transpiration rate $(E)$ of red clover and Festulolium grown in pure stand and in mixture under optimal and drought stress conditions $\left[\mathrm{mmol} \mathrm{H}_{2} \mathrm{O} \mathrm{m}^{-2} \cdot \mathrm{s}^{-1}\right]$ (mean \pm standard deviation, $\left.n=6\right)$

\begin{tabular}{|c|c|c|c|c|c|c|c|c|c|c|}
\hline \multirow{3}{*}{ Treatment } & \multicolumn{2}{|c|}{ I regrowth } & \multicolumn{2}{|c|}{ II regrowth } & \multicolumn{2}{|c|}{ III regrowth } & \multicolumn{2}{|c|}{ IV regrowth } & \multicolumn{2}{|c|}{ Average $^{3}$} \\
\hline & \multicolumn{10}{|c|}{ Soil moisture conditions } \\
\hline & Optimum & Stress & Optimum & Stress & Optimum & Stress & Optimum & Stress & Optimum & Stress \\
\hline \multicolumn{11}{|c|}{2012} \\
\hline Red clover PS ${ }^{1}$ & $3.85 \pm 0.93$ & $1.38 \pm 0.23$ & $4.77 \pm 1.36$ & $2.82 \pm 0.51$ & $2.40 \pm 0.20$ & $1.90 \pm 0.26$ & - & - & $3.67 \pm 0.69$ & $2.04 \pm 0.22$ \\
\hline Red clover $\mathrm{MX}^{2}$ & $3.63 \pm 0.36$ & $2.72 \pm 0.89$ & $2.92 \pm 0.60$ & $2.27 \pm 0.72$ & $2.57 \pm 0.38$ & $2.40 \pm 0.35$ & - & - & $3.04 \pm 0.30$ & $2.46 \pm 0.47$ \\
\hline Festulolium PS & $1.88 \pm 0.18$ & $1.68 \pm 0.25$ & $3.82 \pm 0.56$ & $1.75 \pm 0.36$ & $1.58 \pm 0.45$ & $1.25 \pm 0.24$ & - & - & $2.43 \pm 0.24$ & $1.56 \pm 0.08$ \\
\hline Festulolium MX & $1.57 \pm 0.51$ & $1.38 \pm 0.23$ & $1.87 \pm 0.31$ & $2.10 \pm 0.37$ & $1.33 \pm 0.36$ & $1.07 \pm 0.10$ & - & - & $1.59 \pm 0.17$ & $1.52 \pm 0.06$ \\
\hline $\operatorname{LSD}(\alpha=0.05)$ & \multicolumn{2}{|c|}{0.81} & \multicolumn{2}{|c|}{1.05} & \multicolumn{2}{|c|}{ n.s. ${ }^{4}$} & & & \multicolumn{2}{|c|}{0.53} \\
\hline ANOVA summary & f-ratio & $\mathrm{p}$ & f-ratio & $\mathrm{p}$ & f-ratio & $\mathrm{p}$ & - & - & f-ratio & $\mathrm{p}$ \\
\hline Soil moisture SM & 37.52 & $<0.001$ & 31.87 & $<0.001$ & 12.08 & 0.001 & - & - & 62.60 & $<0.001$ \\
\hline Treatment $\mathrm{T}$ & 25.50 & $<0.001$ & 14.65 & $<0.001$ & 44.01 & $<0.001$ & - & - & 38.94 & $<0.001$ \\
\hline $\mathrm{SM} \times \mathrm{T}$ & 12.17 & $<0.001$ & 7.86 & $<0.001$ & 0.59 & 0.624 & - & - & 10.76 & $<0.001$ \\
\hline \multicolumn{11}{|c|}{2013} \\
\hline Red clover PS & $3.88 \pm 1.01$ & $2.97 \pm 0.35$ & $3.92 \pm 0.97$ & $3.72 \pm 0.85$ & $5.87 \pm 0.77$ & $4.97 \pm 1.04$ & $7.00 \pm 1.46$ & $5.73 \pm 1.75$ & $5.17 \pm 0.50$ & $4.35 \pm 0.35$ \\
\hline Red clover MX & $4.82 \pm 1.75$ & $3.85 \pm 1.73$ & $4.13 \pm 1.24$ & $2.73 \pm 1.40$ & $3.87 \pm 0.45$ & $3.15 \pm 0.36$ & $4.42 \pm 0.84$ & $3.20 \pm 1.0$ & $4.31 \pm 0.72$ & $3.24 \pm 0.39$ \\
\hline Festulolium PS & $4.30 \pm 1.12$ & $2.48 \pm 0.62$ & $3.73 \pm 0.84$ & $3.47 \pm 0.63$ & $5.67 \pm 0.56$ & $3.08 \pm 0.60$ & $6.05 \pm 0.66$ & $4.40 \pm 0.51$ & $4.94 \pm 0.26$ & $3.36 \pm 0.25$ \\
\hline Festulolium MX & $4.90 \pm 1.97$ & $3.47 \pm 1.06$ & $5.25 \pm 1.01$ & $4.33 \pm 0.74$ & $5.40 \pm 1.42$ & $5.28 \pm 0.59$ & $4.52 \pm 0.36$ & $4.38 \pm 0.67$ & $5.02 \pm 0.48$ & $4.37 \pm 0.35$ \\
\hline $\operatorname{LSD}(\alpha=0.05)$ & \multicolumn{2}{|c|}{ n.s. } & \multicolumn{2}{|c|}{1.54} & \multicolumn{2}{|c|}{1.23} & \multicolumn{2}{|c|}{ n.s. } & \multicolumn{2}{|c|}{0.75} \\
\hline ANOVA summary & f-ratio & $\mathrm{p}$ & f-ratio & $\mathrm{p}$ & f-ratio & $\mathrm{p}$ & f-ratio & $\mathrm{p}$ & f-ratio & $\mathrm{p}$ \\
\hline Soil moisture SM & 11.56 & 0.003 & 17.28 & $<0.001$ & 27.46 & $<0.001$ & 13.23 & $<0.001$ & 74.73 & $<0.001$ \\
\hline Treatment $\mathrm{T}$ & 1.79 & 0.061 & 20.78 & $<0.001$ & 17.88 & $<0.001$ & 14.09 & $<0.001$ & 21.23 & $<0.001$ \\
\hline $\mathrm{SM} \times \mathrm{T}$ & 0.37 & 0.828 & 12.38 & $<0.001$ & 4.07 & 0.013 & 1.23 & 0.310 & 3.06 & 0.005 \\
\hline \multicolumn{11}{|c|}{2014} \\
\hline Red clover PS & $4.10 \pm 0.33$ & $2.10 \pm 0.40$ & $6.37 \pm 1.05$ & $3.72 \pm 0.36$ & $2.63 \pm 0.29$ & $1.73 \pm 0.16$ & $6.15 \pm 0.66$ & $4.23 \pm 0.68$ & $4.81 \pm 0.33$ & $2.95 \pm 0.12$ \\
\hline Red clover MX & $2.53 \pm 0.52$ & $2.15 \pm 0.16$ & $5.92 \pm 0.71$ & $3.85 \pm 0.72$ & $3.30 \pm 0.89$ & $2.83 \pm 0.58$ & $5.98 \pm 0.67$ & $4.28 \pm 0.13$ & $4.44 \pm 0.29$ & $3.28 \pm 0.24$ \\
\hline Festulolium PS & $3.08 \pm 0.23$ & $2.40 \pm 0.26$ & $4.55 \pm 0.72$ & $3.70 \pm 0.56$ & $2.40 \pm 0.78$ & $1.40 \pm 0.10$ & $4.48 \pm 0.50$ & $2.12 \pm 0.47$ & $3.63 \pm 0.25$ & $2.41 \pm 0.26$ \\
\hline Festulolium MX & $2.03 \pm 0.28$ & $1.77 \pm 0.29$ & $4.07 \pm 0.24$ & $3.53 \pm 0.28$ & $2.13 \pm 0.36$ & $1.17 \pm 0.21$ & $3.83 \pm 0.45$ & $2.47 \pm 0.83$ & $3.02 \pm 0.18$ & $2.23 \pm 0.18$ \\
\hline $\operatorname{LSD}(\alpha=0.05)$ & \multicolumn{2}{|c|}{0.51} & \multicolumn{2}{|c|}{0.99} & \multicolumn{2}{|c|}{ n.s. } & \multicolumn{2}{|c|}{ n.s. } & \multicolumn{2}{|c|}{0.38} \\
\hline ANOVA summary & f-ratio & $\mathrm{p}$ & f-ratio & $\mathrm{p}$ & f-ratio & $p$ & f-ratio & $\mathrm{p}$ & f-ratio & $\mathrm{p}$ \\
\hline Soil moisture SM & 77.10 & $<0.001$ & 68.12 & $<0.001$ & 32.09 & $<0.001$ & 117.20 & $<0.001$ & 316.7 & $<0.001$ \\
\hline Treatment $\mathrm{T}$ & 29.67 & $<0.001$ & 10.40 & $<0.001$ & 17.62 & $<0.001$ & 43.58 & $<0.001$ & 78.14 & $<0.001$ \\
\hline $\mathrm{SM} \times \mathrm{T}$ & 17.65 & $<0.001$ & 7.32 & $<0.001$ & 0.71 & 0.551 & 1.52 & 0.223 & 10.06 & $<0.001$ \\
\hline
\end{tabular}

${ }^{1} \mathrm{PS}$ - species grown in pure stand; ${ }^{2} \mathrm{MX}$ - species grown in mixture; ${ }^{3}$ average over the three (2012) or four regrowth (2013, 2014); ${ }^{4}$ n.s. - not significant 
Table 3. Stomatal conductance ( $g_{s}$ ) of red clover and Festulolium grown in pure stand and in mixture under optimal and drought stress conditions $\left[\mathrm{mmol} \mathrm{H}_{2} \mathrm{O} \mathrm{m}^{-2} \mathrm{~s}^{-1}\right]$ (mean \pm standard deviation, $n=6$ )

\begin{tabular}{|c|c|c|c|c|c|c|c|c|c|c|}
\hline \multirow{3}{*}{ Treatment } & \multicolumn{2}{|c|}{ I regrowth } & \multicolumn{2}{|c|}{ II regrowth } & \multicolumn{2}{|c|}{ III regrowth } & \multicolumn{2}{|c|}{ IV regrowth } & \multicolumn{2}{|c|}{ Average $^{3}$} \\
\hline & \multicolumn{10}{|c|}{ Soil moisture conditions } \\
\hline & Optimum & Stress & Optimum & Stress & Optimum & Stress & Optimum & Stress & Optimum & Stress \\
\hline \multicolumn{11}{|c|}{2012} \\
\hline Red clover PS ${ }^{1}$ & $208 \pm 85$ & $47 \pm 9$ & $224 \pm 34$ & $149 \pm 26$ & $398 \pm 55$ & $427 \pm 123$ & - & - & $276 \pm 28$ & $207 \pm 44$ \\
\hline Red clover $\mathrm{MX}^{2}$ & $132 \pm 28$ & $75 \pm 28$ & $162 \pm 25$ & $166 \pm 20$ & $643 \pm 191$ & $448 \pm 105$ & - & - & $312 \pm 61$ & $230 \pm 36$ \\
\hline Festulolium PS & $53 \pm 4$ & $40 \pm 10$ & $183 \pm 22$ & $149 \pm 16$ & $349 \pm 161$ & $267 \pm 76$ & - & - & $195 \pm 54$ & $152 \pm 21$ \\
\hline Festulolium MX & $48 \pm 17$ & $40 \pm 19$ & $153 \pm 24$ & $172 \pm 11$ & $294 \pm 162$ & $216 \pm 40$ & - & - & $165 \pm 57$ & $143 \pm 17$ \\
\hline $\operatorname{LSD}(\alpha=0.05)$ & \multicolumn{2}{|c|}{54.4} & \multicolumn{2}{|c|}{36.5} & \multicolumn{2}{|c|}{ n.s. ${ }^{4}$} & & & \multicolumn{2}{|c|}{ n.s. } \\
\hline ANOVA summary & f-ratio & $\mathrm{p}$ & f-ratio & $\mathrm{p}$ & f-ratio & $\mathrm{p}$ & - & - & f-ratio & $\mathrm{p}$ \\
\hline Soil moisture SM & 34.51 & $<0.001$ & 10.06 & 0.003 & 5.04 & 0.030 & - & - & 18.96 & $<0.001$ \\
\hline Treatment $\mathrm{T}$ & 16.88 & $<0.001$ & 2.65 & 0.062 & 12.47 & $<0.001$ & - & - & 19.71 & $<0.001$ \\
\hline $\mathrm{SM} \times \mathrm{T}$ & 12.26 & $<0.001$ & 9.44 & $<0.001$ & 1.59 & 0.206 & - & - & 1.17 & 0.333 \\
\hline \multicolumn{11}{|c|}{2013} \\
\hline Red clover PS & $529 \pm 113$ & $281 \pm 51$ & $323 \pm 36$ & $296 \pm 106$ & $347 \pm 175$ & $308 \pm 106$ & $424 \pm 210$ & $375 \pm 208$ & $406 \pm 74$ & $315 \pm 62$ \\
\hline Red clover MX & $406 \pm 242$ & $271 \pm 159$ & $160 \pm 64$ & $81 \pm 27$ & $332 \pm 74$ & $154 \pm 20$ & $527 \pm 84$ & $197 \pm 86$ & $356 \pm 65$ & $176 \pm 26$ \\
\hline Festulolium PS & $316 \pm 180$ & $203 \pm 72$ & $207 \pm 75$ & $181 \pm 17$ & $564 \pm 82$ & $131 \pm 34$ & $773 \pm 96$ & $285 \pm 71$ & $465 \pm 64$ & $200 \pm 15$ \\
\hline Festulolium MX & $431 \pm 353$ & $219 \pm 114$ & $412 \pm 28$ & $150 \pm 39$ & $502 \pm 190$ & $373 \pm 136$ & $753 \pm 83$ & $446 \pm 172$ & $525 \pm 109$ & $297 \pm 83$ \\
\hline $\operatorname{LSD}(\alpha=0.05)$ & \multicolumn{2}{|c|}{ n.s. } & \multicolumn{2}{|c|}{88.0} & \multicolumn{2}{|c|}{182.7} & \multicolumn{2}{|c|}{214.5} & \multicolumn{2}{|c|}{106.2} \\
\hline ANOVA summary & f-ratio & $\mathrm{p}$ & f-ratio & $\mathrm{p}$ & f-ratio & $\mathrm{p}$ & f-ratio & $\mathrm{p}$ & f-ratio & $\mathrm{p}$ \\
\hline Soil moisture SM & 10.96 & 0.002 & 38.25 & $<0.001$ & 32.56 & $<0.001$ & 53.85 & $<0.001$ & 93.62 & $<0.001$ \\
\hline Treatment $\mathrm{T}$ & 1.24 & 0.307 & 29.02 & $<0.001$ & 5.48 & 0.003 & 7.69 & $<0.001$ & 9.48 & $<0.001$ \\
\hline $\mathrm{SM} \times \mathrm{T}$ & 0.35 & 0.786 & 11.38 & $<0.001$ & 6.14 & 0.001 & 5.17 & 0.004 & 3.59 & 0.022 \\
\hline \multicolumn{11}{|c|}{2014} \\
\hline Red clover PS & $481 \pm 62$ & $146 \pm 31$ & $602 \pm 105$ & $190 \pm 44$ & $785 \pm 96$ & $318 \pm 110$ & $642 \pm 64$ & $323 \pm 112$ & $628 \pm 27$ & $244 \pm 31$ \\
\hline Red clover MX & $361 \pm 98$ & $198 \pm 26$ & $597 \pm 93$ & $219 \pm 89$ & $795 \pm 142$ & $757 \pm 62$ & $614 \pm 137$ & $284 \pm 52$ & $592 \pm 41$ & $364 \pm 25$ \\
\hline Festulolium PS & $264 \pm 49$ & $147 \pm 26$ & $313 \pm 96$ & $201 \pm 39$ & $448 \pm 153$ & $191 \pm 39$ & $418 \pm 63$ & $115 \pm 39$ & $361 \pm 38$ & $164 \pm 22$ \\
\hline Festulolium MX & $292 \pm 55$ & $147 \pm 50$ & $297 \pm 55$ & $198 \pm 34$ & $580 \pm 183$ & $208 \pm 80$ & $348 \pm 43$ & $154 \pm 87$ & $379 \pm 52$ & $177 \pm 23$ \\
\hline $\operatorname{LSD}(\alpha=0.05)$ & \multicolumn{2}{|c|}{84.6} & \multicolumn{2}{|c|}{115.8} & \multicolumn{2}{|c|}{182.2} & \multicolumn{2}{|c|}{ n.s. } & \multicolumn{2}{|c|}{53.3} \\
\hline ANOVA summary & f-ratio & $\mathrm{p}$ & f-ratio & $\mathrm{p}$ & f-ratio & $p$ & f-ratio & $\mathrm{p}$ & f-ratio & $\mathrm{p}$ \\
\hline Soil moisture SM & 144.60 & $<0.001$ & 134.32 & $<0.001$ & 69.40 & $<0.001$ & 147.16 & $<0.001$ & 643.46 & $<0.001$ \\
\hline Treatment T & 10.28 & $<0.001$ & 16.17 & $<0.001$ & 35.23 & $<0.001$ & 26.08 & $<0.001$ & 120.86 & $<0.001$ \\
\hline $\mathrm{SM} \times \mathrm{T}$ & 9.75 & $<0.001$ & 15.06 & $<0.001$ & 7.34 & $<0.001$ & 1.79 & 0.165 & 19.67 & $<0.001$ \\
\hline
\end{tabular}

${ }^{1} \mathrm{PS}$ - species grown in pure stand; ${ }^{2} \mathrm{MX}$ - species grown in mixture; ${ }^{3}$ average over the three (2012) or four regrowth (2013, 2014); ${ }^{4}$ n.s. - not significant 
Table 4. Water use efficiency (WUE) of red clover and Festulolium grown in pure stand and in mixture under optimal and drought stress conditions [umol $\mathrm{CO}_{2} \cdot \mathrm{md}^{-1}$ of air] (mean \pm standard deviation, $n=6$ )

\begin{tabular}{|c|c|c|c|c|c|c|c|c|c|c|}
\hline \multirow{3}{*}{ Treatment } & \multicolumn{2}{|c|}{ I regrowth } & \multicolumn{2}{|c|}{ II regrowth } & \multicolumn{2}{|c|}{ III regrowth } & \multicolumn{2}{|c|}{ IV regrowth } & \multicolumn{2}{|c|}{ Average $^{3}$} \\
\hline & \multicolumn{10}{|c|}{ Soil moisture conditions } \\
\hline & Optimum & Stress & Optimum & Stress & Optimum & Stress & Optimum & Stress & Optimum & Stress \\
\hline \multicolumn{11}{|c|}{2012} \\
\hline Red clover PS ${ }^{1}$ & $1.26 \pm 0.39$ & $2.45 \pm 0.99$ & $1.41 \pm 0.27$ & $1.57 \pm 0.33$ & $8.23 \pm 0.86$ & $9.72 \pm 1.51$ & - & - & $2.86 \pm 0.37$ & $4.27 \pm 0.52$ \\
\hline Red clover $\mathrm{MX}^{2}$ & $2.16 \pm 0.55$ & $1.82 \pm 0.76$ & $1.39 \pm 0.22$ & $1.77 \pm 0.37$ & $8.11 \pm 1.48$ & $8.50 \pm 1.48$ & - & - & $3.56 \pm 0.49$ & $3.92 \pm 0.54$ \\
\hline Festulolium PS & $3.64 \pm 0.54$ & $3.90 \pm 0.41$ & $0.91 \pm 0.11$ & $1.46 \pm 0.27$ & $6.43 \pm 1.72$ & $7.72 \pm 2.60$ & - & - & $2.77 \pm 0.45$ & $3.91 \pm 0.49$ \\
\hline Festulolium MX & $3.29 \pm 0.57$ & $3.65 \pm 0.90$ & $1.49 \pm 0.30$ & $1.20 \pm 0.05$ & $5.24 \pm 0.17$ & $6.12 \pm 1.08$ & - & - & $3.11 \pm 0.42$ & $2.92 \pm 0.32$ \\
\hline $\operatorname{LSD}(\alpha=0.05)$ & \multicolumn{2}{|c|}{ n.s. ${ }^{4}$} & \multicolumn{2}{|c|}{0.41} & \multicolumn{2}{|c|}{ n.s. } & & \multicolumn{3}{|r|}{0.71} \\
\hline ANOVA summary & f-ratio & $\mathrm{p}$ & f-ratio & $\mathrm{p}$ & f-ratio & $\mathrm{p}$ & - & - & f-ratio & $\mathrm{p}$ \\
\hline Soil moisture SM & 3.49 & 0.069 & 6.78 & 0.013 & 3.73 & 0.060 & - & - & 26.23 & $<0.001$ \\
\hline Treatment $\mathrm{T}$ & 25.68 & $<0.001$ & 5.13 & 0.004 & 13.25 & $<0.001$ & - & - & 5.45 & 0.003 \\
\hline $\mathrm{SM} \times \mathrm{T}$ & 2.59 & 0.066 & 5.62 & 0.002 & 0.53 & 0.661 & - & - & 7.65 & $<0.001$ \\
\hline \multicolumn{11}{|c|}{2013} \\
\hline Red clover PS & $3.12 \pm 0.45$ & $3.01 \pm 0.42$ & $3.85 \pm 0.62$ & $3.86 \pm 0.61$ & $3.23 \pm 0.38$ & $2.87 \pm 0.71$ & $1.24 \pm 0.20$ & $1.28 \pm 0.29$ & $2.62 \pm 0.19$ & $2.58 \pm 0.12$ \\
\hline Red clover MX & $2.70 \pm 0.68$ & $2.56 \pm 0.89$ & $1.72 \pm 0.27$ & $2.58 \pm 0.97$ & $2.54 \pm 0.24$ & $2.88 \pm 0.21$ & $1.63 \pm 0.37$ & $1.85 \pm 0.29$ & $2.11 \pm 0.21$ & $2.33 \pm 0.35$ \\
\hline Festulolium PS & $2.55 \pm 0.83$ & $3.32 \pm 0.51$ & $2.54 \pm 0.41$ & $2.89 \pm 0.39$ & $2.60 \pm 0.24$ & $2.81 \pm 0.25$ & $1.31 \pm 0.16$ & $1.29 \pm 0.15$ & $2.12 \pm 0.22$ & $2.40 \pm 0.21$ \\
\hline Festulolium MX & $2.42 \pm 0.65$ & $3.01 \pm 0.79$ & $2.26 \pm 0.68$ & $2.65 \pm 0.34$ & $2.87 \pm 0.35$ & $2.25 \pm 0.47$ & $1.90 \pm 0.25$ & $1.58 \pm 0.37$ & $2.32 \pm 0.24$ & $2.31 \pm 0.39$ \\
\hline $\operatorname{LSD}(\alpha=0.05)$ & \multicolumn{2}{|c|}{ n.s. } & \multicolumn{2}{|c|}{ n.s. } & \multicolumn{2}{|c|}{0.61} & \multicolumn{2}{|c|}{ n.s. } & \multicolumn{2}{|c|}{$\begin{array}{l}\text { n.s. } \\
\end{array}$} \\
\hline ANOVA summary & f-ratio & $\mathrm{p}$ & f-ratio & $\mathrm{p}$ & f-ratio & $\mathrm{p}$ & f-ratio & $\mathrm{p}$ & f-ratio & $\mathrm{p}$ \\
\hline Soil moisture SM & 2.00 & 0.164 & 5.68 & 0.022 & 0.85 & 0.362 & 0.07 & 0.795 & 2.26 & 0.140 \\
\hline Treatment $\mathrm{T}$ & 1.04 & 0.386 & 19.75 & $<0.001$ & 3.32 & 0.029 & 11.39 & $<0.001$ & 5.07 & 0.004 \\
\hline $\mathrm{SM} \times \mathrm{T}$ & 1.43 & 0.247 & 1.09 & 0.363 & 4.05 & 0.013 & 1.95 & 0.137 & 1.17 & 0.334 \\
\hline \multicolumn{11}{|c|}{2014} \\
\hline Red clover PS & $5.55 \pm 0.36$ & $5.97 \pm 0.97$ & $3.71 \pm 0.50$ & $4.21 \pm 0.30$ & $8.81 \pm 1.26$ & $9.38 \pm 1.29$ & $2.12 \pm 0.22$ & $2.24 \pm 0.24$ & $4.25 \pm 0.26$ & $4.54 \pm 0.23$ \\
\hline Red clover MX & $8.13 \pm 1.50$ & $8.18 \pm 1.01$ & $3.90 \pm 0.85$ & $4.04 \pm 0.57$ & $6.87 \pm 1.75$ & $7.69 \pm 1.72$ & $1.86 \pm 0.08$ & $2.46 \pm 0.60$ & $4.26 \pm 0.40$ & $4.95 \pm 0.39$ \\
\hline Festulolium PS & $4.93 \pm 0.31$ & $5.20 \pm 0.34$ & $2.78 \pm 0.29$ & $2.97 \pm 0.38$ & $5.06 \pm 1.56$ & $7.61 \pm 0.99$ & $1.76 \pm 0.22$ & $2.75 \pm 0.50$ & $3.23 \pm 0.20$ & $4.15 \pm 0.34$ \\
\hline Festulolium MX & $6.51 \pm 1.76$ & $6.69 \pm 0.60$ & $2.89 \pm 0.27$ & $3.13 \pm 0.46$ & $6.52 \pm 0.54$ & $8.09 \pm 1.27$ & $2.50 \pm 0.37$ & $2.01 \pm 0.38$ & $3.96 \pm 0.30$ & $4.12 \pm 0.25$ \\
\hline $\operatorname{LSD}(\alpha=0.05)$ & \multicolumn{2}{|c|}{ n.s. } & \multicolumn{2}{|c|}{ n.s. } & \multicolumn{2}{|c|}{ n.s. } & \multicolumn{2}{|c|}{0.57} & \multicolumn{2}{|c|}{0.47} \\
\hline ANOVA summary & f-ratio & $\mathrm{p}$ & f-ratio & $\mathrm{p}$ & f-ratio & $\mathrm{p}$ & f-ratio & $\mathrm{p}$ & f-ratio & $\mathrm{p}$ \\
\hline Soil moisture SM & 0.63 & 0.431 & 3.46 & 0.070 & 12.38 & 0.001 & 8.27 & 0.006 & 33.08 & $<0.001$ \\
\hline Treatment T & 20.98 & $<0.001$ & 17.30 & $<0.001$ & 8.67 & $<0.001$ & 0.23 & 0.873 & 20.57 & $<0.001$ \\
\hline $\mathrm{SM} \times \mathrm{T}$ & 0.07 & 0.974 & 0.34 & 0.800 & 1.28 & 0.293 & 9.15 & $<0.001$ & 3.94 & 0.014 \\
\hline
\end{tabular}

${ }^{1} \mathrm{PS}$ - species grown in pure stand; ${ }^{2} \mathrm{MX}$ - species grown in mixture; ${ }^{3}$ average over the three (2012) or four regrowth (2013, 2014); ${ }^{4}$ n.s. - not significant 
Soil moisture was an important factor shaping the level of dry matter yield of red clover and Festulolium cultivated in pure and mixed stands. Regardless of the method of cultivation, both species generally responded with yield reduction under long-term stress (Table 5). The highest decrease in total yield was noted in red clover cultivated in pure stand (PS) - by $34.9 \%$ in the first, by $33.7 \%$ in the second, and by $22.7 \%$ in the third year of vegetation, whereas this decrease was smaller in the mixture (by 10.1, 26.9, and 19.3\%, respectively). Festulolium hybrid grown in pure stand turned out to be the least sensitive to drought. In the first year of vegetation ( $1^{\text {st }}$ and $2^{\text {nd }}$ regrowth $)$ and in the second and third year of vegetation (1st regrowth), it showed a higher relative dry matter yield under soil deficit than under optimal water conditions. The reduction in total dry matter yield of red clover and Festulolium, expressed as an agricultural drought index (YR), ranged from - 0.061 to 0.349 in the first, from 0.212 to 0.337 in the second, and from 0.104 to 0.227 in the third year of vegetation (Fig. 4). The highest values of the YR index were recorded in the pure stand of red clover, while the smallest - for Festulolium hybrid. The yield reduction in mixed crops was on an average level.

\section{Discussion}

Water is one of the most important environmental resources determining plant productivity. Plants' response to water deficit is complex. It includes adaptation changes and harmful effects of water stress, as a result of which there occurs disturbance in fundamental life processes. One of the effects of these changes is reduction or inhibition of growth. It results from the reduction of the intensity of gas exchange processes, a decrease in the export of photosynthesis products from leaves to other organs of the plants, and the disruption in transport and distribution of assimilates. Water shortage also inhibits the growth of plants, including leaf blades, which due to their reduced surface, receive less light and absorb less carbon dioxide (Starck, 2010). Our studies showed that red clover and Festulolium yielded lower in drought stress conditions. The biggest decline in the total yield was recorded for red clover grown in pure stand (on average by $30.2 \%$ for three years), lower in a mixture (by 19.3\%), and the smallest in Festulolium in pure stand (by $9.5 \%$ ). Adopting the level of agricultural yield decrease as a criterion of crop resistance to stress, allowed to conclude that Festulolium hybrid grown in pure stand was the most resistant to the effects of long-term stress. Red clover grown in pure stand showed the greatest sensitivity to drought, while in the mixture with Festulolium, its yield loss was smaller by $10.9 \%$. Similar results were obtained by the authors in studies on the response of alfalfa (Medicago $\times$ varia Martyn) to water deficit in the soil depending on the type of sowing (Staniak et al., 2018). Under stress conditions, the yield decrease of alfalfa grown in pure stand was by $13 \%$ higher compared to the cultivation in a mixture with Festulolium. Studies of Küchenmeister et al. (2013) showed that yellow alfalfa (Medicago falcata L.), white clover (Trifolium repens L.) and birdsfoot trefoil (Lotus uliginosus Schkuhr) grown in a mixture with perennial ryegrass (Lolium perenne L.) responded to stress with a much lower yield decrease than in pure stand. Tucak et al. (2016) showed high sensibility of red clover grown in pure stand to stressful conditions caused by drought resulted in low yields in 23 cultivars and populations. Also Gaudin et al. (2013) reported about the high sensibility of red clover in pure stand to drought stress. Studies of AbdElgawad et al. (2015) showed that water deficit reduced biomass of legumes (black medic (Medicago lupulina L.) and birdsfoot trefoil) and grasses (meadow bluegrass (Poa pratensis L.) 


$$
-226-
$$

and perennial ryegrass) at the dry weight and fresh weight levels, but this effect was stronger in the legumes species.

Table 5. Relative [\%] dry mass yield (DMY) of red clover and Festulolium grown in pure stand and in mixture under drought stress in relation to optimal conditions

\begin{tabular}{|c|c|c|c|c|c|}
\hline \multirow{2}{*}{ Treatment } & \multicolumn{4}{|c|}{ Regrowth } & \multirow{2}{*}{ Total DMY ${ }^{3}$} \\
\hline & I & II & III & IV & \\
\hline \multicolumn{6}{|c|}{2012} \\
\hline Red clover PS ${ }^{1}$ & 61.7 & 65.7 & 74.9 & - & 65.1 \\
\hline Festulolium PS & 128.7 & 106.4 & 86.9 & - & 109.5 \\
\hline Red clover + Festulolium $\mathrm{MX}^{2}$ & 98.3 & 83.8 & 81.9 & - & 89.9 \\
\hline \multicolumn{6}{|c|}{2013} \\
\hline Red clover PS ${ }^{1}$ & 67.0 & 63.6 & 63.3 & 71.8 & 66.3 \\
\hline Festulolium PS & 85.3 & 81.3 & 71.3 & 73.3 & 79.0 \\
\hline Red clover + Festulolium $\mathrm{MX}^{2}$ & 70.1 & 77.2 & 67.3 & 83.5 & 73.1 \\
\hline \multicolumn{6}{|c|}{2014} \\
\hline Red clover PS ${ }^{1}$ & 96.4 & 75.0 & 59.1 & 70.2 & 77.3 \\
\hline Festulolium PS & 103.3 & 84.8 & 85.3 & 84.4 & 89.6 \\
\hline Red clover + Festulolium $\mathrm{MX}^{2}$ & 93.0 & 80.5 & 78.6 & 76.2 & 83.4 \\
\hline \multicolumn{6}{|c|}{ Sum of three years } \\
\hline Red clover PS ${ }^{1}$ & 73.0 & 68.9 & 64.1 & 71.1 & 69.8 \\
\hline Festulolium PS & 103.1 & 90.3 & 81.6 & 78.2 & 90.5 \\
\hline Red clover + Festulolium $\mathrm{MX}^{2}$ & 84.2 & 80.5 & 74.8 & 79.9 & 80.7 \\
\hline
\end{tabular}

${ }^{1} \mathrm{PS}-$ species grown in pure stand

${ }^{2} \mathrm{MX}$ - species grown in mixture

${ }^{3}$ Total DMY is the sum of dry mass yield over the three (2012) or four regrowth $(2013,2014)$

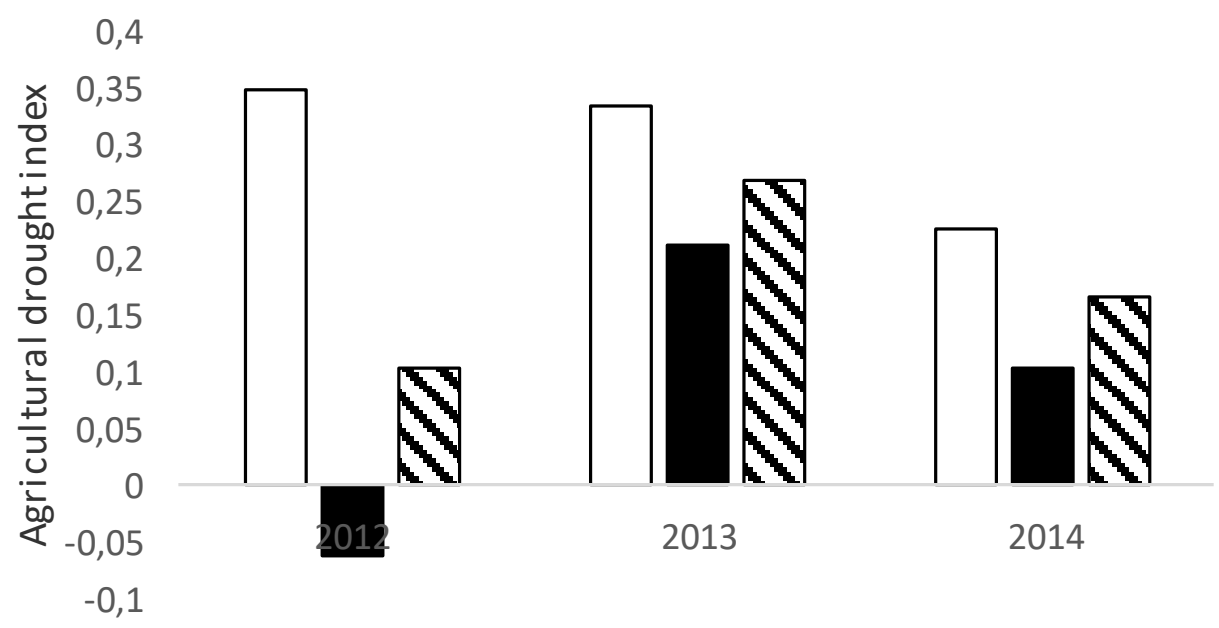

$\square$ Red clover $\mathbf{D}$ Festulolium $\boldsymbol{\square}$ Mixture

Figure 4. Agricultural drought index for red clover, Festulolium and mixture under drought stress conditions 
Inhibition of plant growth in drought conditions is a defensive response of plants. Water deficit in the soil affects the reduction of water potential of plant shoots and stimulates the growth of the root. As a result, the plant changes its distribution of assimilates, which in turn causes a lower yield of the aboveground mass (Lucero et al., 1999). According to Lazzarotto et al. (2009) as well as Skinner and Comas (2010) higher resistance in grasses than legumes species to drought could possibly be related to an increased root/shoot ratio under stress conditions, improving water and nutrient use. Lucero et al. (1999) observed that increased soil water deficit decreased root dry matter yield for perennial ryegrass grown in pure stand, but in mixture with white clover root yield decrease was smaller. Many authors underline also that the productivity of mixed crops is influenced by the competition of the plants and their mutual impact on each other. According to Frankow-Lindgerg (1986), an intraspecific competition more strongly affects the productivity of red clover, while the interspecific one - of grasses. Hence, growing red clover together with grasses is a very good practice.

Photosynthesis is one of the most stress-sensitive life processes. Factors limiting the photosynthetic activity of plants include: water, carbon dioxide, temperature, and light. The influence of water is not direct, as the water content in chloroplasts is sufficient for photosynthesis. Water, however, strongly affects $\mathrm{CO}_{2}$ assimilation, as under water deficit, stomata close and $\mathrm{CO}_{2}$ input gets cut off, which reduces its concentration in the intercellular spaces and hence, photosynthesis is inhibited (Córdobaa et al., 2015). In grasses, a big decrease of photosynthesis can result from the increased participation of photorespiration in gas exchange, which often intensifies under stress, as one of the mechanisms of energy dissipation (Flexas and Medrano, 2002). Our studies have shown that drought stress caused a significant reduction in the rate of photosynthesis and transpiration in the tested plants, regardless of the species and way of cultivation, whereas the highest sensitivity to stress was recorded for red clover grown in pure stand, while the smallest - for hybrid Festulolium cultivated in the mixture. Studies of Olszewska (2008) showed a higher rate of photosynthesis and transpiration in Festulolium hybrid grown in a mixture with white clover (respectively by 49 and 57\%) and birdsfoot trefoil (respectively by 24 and 34\%) compared to the pure stand. In turn, the studies AbdElgawad et al. (2015) showed that legumes (black medic and birdfoot trefoil) exhibit a significantly a higher photosynthesis rate under optimal conditions, but under drought conditions, they limited this process stronger than grasses (perennial ryegrass and meadow bluegrass). According to Dziadczyk (2002), the plant is resistant to stress if it can keep the intensity of the most important life processes on the least changed level in environmental conditions significantly deviating from the optimum.

The survival of plants in drought conditions depends on efficient water management, which is well expressed by water use efficiency index (WUE). It is dependent on the intensity of the photosynthesis and transpiration processes, but also reflects the influence of environmental factors. Our studies have shown that values of WUE index in the tested plant species were higher under stress conditions than under optimal soil moisture in the first and third year of vegetation, especially in the case Festulolium hybrids. Studies of Olszewska (2008) showed a significantly higher value of WUE index in Festulolium grown in a mixture with white clover and birdsfoot trefoil, but only in the first of the three years of vegetation. This proves that Festulolium has a more economical water management and greater resistance to drought stress compared to clover. According to Hall (1990), a high value of WUE index allowed to maintain a high coefficient of crop yields even during drought. In turn, Blum (2009) believes that 
WUE index is not associated with drought resistance, as some species resistant to drought show lower WUE values, which is associated with a deeper root system and higher use of water. According to this author, the increase in crop yields under drought conditions is closely connected with the growth and development of the root system, especially at the beginning of the growing season.

\section{Conclusions}

The present experiment indicates, that a long-term stress caused by water deficit in the soil significantly reduced the yield of dry mass of red clover and Festulolium, regardless of the method of cultivation. Mixtures showed smaller yield losses under drought stress compared to red clover grown in pure stand, which indicates their higher suitability to be grown in areas with less rainfall. Photosynthetic effectiveness of red clover was higher than Festulolium, regardless of the level of soil moisture. In terms of long-term drought, the photosynthesis and transpiration rate in the tested species were lower than in the treatments optimally moisturized. Red clover grown in pure stand responded to stress the most, while Festulolium hybrid cultivated in the mixture - the least. The water use efficiency index (WUE) of the tested plant species was higher under stress caused by water deficit in the soil than under optimal conditions, whereas significant differences were reported in the first and third year of vegetation. The biggest differences were noted in Festulolium, which proves a more economical water management of this hybrid compared to red clover. The selection of crop with high water use efficiency (WUE) traits would be one of the adaptation measures for climate change.

Our studies have shown, that the cultivation of red clover in a mixture with Festulolium hybrid is more favorable than in pure stand, especially in areas with less rainfall, due to better yields and higher durability resulting from, i.e. a more efficient water management. It is associated with course of the main physiological processes. Red clover reacted to soil water deficit with a significant decrease of the rate of photosynthesis and transpiration but stronger reaction was observed in pure sowing than in mixture.

Acknowledgements. The studies have been supported by the Polish Ministry of Science and Higher Education within the statutory activity of the Institute of Soil Science and Plant Cultivation - State Research Institute, task 1.01 "Evaluation of resistance to drought stress of Festulolium braunii and its mixtures with selected legume species".

\section{REFERENCES}

[1] AbdElgawad, H., Farfan-Vignolo, E. R., de Vos, D., Asard, H. (2015): Elevated $\mathrm{CO}_{2}$ mitigates drought and temperature-induced oxidative stress differently in grasses and legumes. - Plant Science 231: 1-10.

[2] Blum, A. (2009): Effective use of water (EUW) and not water-use efficiency (WUE) is the target of crop yield improvement under drought stress. - Field Crops Research 112: 119-123.

[3] Córdobaa, J., Molina-Canob, J. L., Péreza, P., Morcuendea, R., Moralejoc, M., Savéd, R., Martínez-Carrascoa, R. (2015): Photosynthesis-dependent/independent control of 
stomatal responses to $\mathrm{CO} 2$ in mutant barley with surplus electron transport capacity and reduced SLAH3 anion channel transcript. - Plant Science 239: 15-25.

[4] Dziadczyk, P. (2002): Genetic tolerance to abiotic stress in plants. - Zeszyty Problemowe Postępów Nauk Rolniczych 481: 49-60.

[5] Elgersma, A., Søegaard, K. (2018): Changes in nutritive value and herbage yield during extended growth intervals in grass-legume mixtures: effects of species, maturity at harvest, and relationships between productivity and components of feed quality. - Grass and Forage Science 73: 78-93.

[6] Ergon, A., Seddaiu, G., Korhonen, P., Virkajärvi, P., Bellocchi, G., Jørgensen, M., Østrem, L., Reheul, D., Volaire, F. (2018): How can forage production in Nordic and Mediterranean Europe adapt to the challenges and opportunities arising from climate change? - European Journal of Agronomy 92: 97-106.

[7] Flexas, J., Medrano, H. (2002): Drought-inhibition of photosynthesis in C-3 plants: Stomatal and nonstomatal limitation revisited. - Annals of Botany 89: 183-189.

[8] Frankow-Lindgerg, B. E. (1986): Competition in field-sown swards of lucerne or red clover and timothy. - Swedish Journal of Agricultural Research 16: 119-128.

[9] Gaudin, A. C. M., Westra, S., Loucks, C. E. S., Janovieck, K., Martin, R. C., Deen, W. (2013): Improving resilience of northern field crop systems using inter-seeded red clover: a review. - Agronomy Journal 3(1): 148-180.

[10] Hakala, K., Jauhiainen, L. (2007): Yield and nitrogen concentration of above- and belowground biomasses or red clover cultivars in pure stands and in mixtures with three grass species in northern Europe. - Grass and Forage Science 62: 312-321.

[11] Hall, A. E. (1990): Plant adaptation to hot and dry stresses in relation to horticultural plant breeding. - XXII Inter. Hort. Congr. Plenary lectures S., p. 44-48, Florence, Italy.

[12] Hura, T., Hura, K., Grzesiak, M., Rzepka, A. (2007): Effect of long-term drought stress on leaf gas exchange and fluorescence parameters in C3 and C4 plants. - Acta Physiology Plantarum 29: 103-113.

[13] Jensen, E. S., Hauggaard-Nielsen, H. (2003): How can increased use of biological N2 fixation in agriculture benefit the environment? - Plant and Soil 252: 177-186.

[14] Kryszak, J., Domański, P., Jokś, W. (2002): Use value of Festulolium braunii (K. Richter) A. Camus cultivars registered in Poland. - Grassland Science in Europe 7: 436437.

[15] Küchenmeister, K., Küchenmeister, F., Kayser, M., Wrage-Mönnig, N., Isselstein, J. (2013): Influence of drought stress on nutritive value of perennial forage legumes. International Journal of Plant Production 7(4): 693-710.

[16] Łabędzki, L. (2006): Droughts and Floods - A Threat to Agriculture. - In: Mioduszewski, W. (ed.) Water in Agricultural Landscape. Water, Environment, Rural Areas, Poland.

[17] Lawlor, D. W. (1995): Photosynthesis, productivity and environment. - Journal of Experimental Botany 46: 1449-1461.

[18] Lazzarotto, P., Calanca, P., Fuhrer, J. (2009): Dynamics of grass-clover mixtures-an analysis of the response to management with the productive grassland simulator (PROGRASS). - Ecological Modelling 220: 703-724.

[19] Li, P., Chen, J., Wu, P. (2011): Agronomic characteristics and grain yield of 30 spring wheat genotypes under drought stress and non-stress conditions. - Agronomy Journal 103(6): 1619-1628.

[20] Lipiec, J., Doussan, C., Nosalewicz, A., Kondracka, K. (2013): Effect of drought and heat stresses on plant growth and yield: a review. - International Agrophysics 27: 463-477.

[21] Lucero, D. W., Grieu, P., Guckert, A. (1999): Effects of water deficit and plant interaction on morphological growth parameters and yield of white clover (Trifolium repens L.) and ryegrass (Lolium perenne L.) mixtures. - European Journal of Agronomy 11: 167-177. 
[22] Olszewska, M. (2008): Gas exchange parameters in Festulolium braunii (K. Richt.) A. Camus grown in mixtures with legumes depending on multiple nitrogen rates. - Polish Journal of Natural Science 23(1): 48-72.

[23] OMAFRA (Ontario Ministry of Agriculture, Food and Rural Affairs) (2011): Red Clover. Cover Crops. - Ontario Ministry of Agriculture, Food and Rural Affairs, Ontario. http://www.omafra.gov.on.ca/english/crops/facts/cover_crops01/redclover.htm (accessed: 31.08.2018).

[24] Østrem, L., Volden, B., Larsen, A. (2013): Morphology, dry matter yield and phonological characters at different maturity stages of Festulolium compared with other grass species. - Acta Agriculture Scandinavica, sec B - Soil and Plant Science 63: 531542.

[25] Queen, A., Earl, H., Deen, W. (2009): Light and moisture competition effects on biomass of red clover under-seeded to winter wheat. - Agronomy Journal 101(6): 1511-1521.

[26] Rojek, S. (1986): Water requirements of papilionaceous plants. - Fragmenta Agronomica 2(10): 3-20.

[27] Skinner, R. H., Comas, L. H. (2010): Root distribution of temperate forage species subjected to water and nitrogen stress. - Crop Science 50: 2178-2185.

[28] Staniak, M., Bojarszczuk, J., Księżak, J. (2018): Changes in yield, gas exchange parameters, and chemical composition in Festulolium and alfalfa grown in pure sowing and in mixture under drought stress. - Acta Agriculture Scandinavica, sec B - Soil Plant Sci. 68(3): 255-263.

[29] Starck, Z. (2010): Effect of stress conditions on coordination of photosynthetic production and resources allocation. - Postępy Nauk Rolmiczych 1: 9-26.

[30] Thomas, H. (1994): Diversity between and within temperate forage grass species in drought resistance, water use and related physiological responses. - Aspects of Applied Biology 38: 47-55.

[31] Tucak, M., Popović, S., Čupić, T., Krizmanić, G., Španić, V., Meglič, V., Radović, J. (2016): Assessment of red clover (Trifolium pratense L.) productivity in environmental stress. - Poljoprivreda/Agriculture 22(2): 3-9. 